\title{
Minireview
}

\section{Interleukin-6: historical background, genetics and biological significance}

\author{
Monique C. J. Wolvekamp and Richard L. Marquet \\ Department of Surgery, Erasmus University, Rotterdam, The Netherlands
}

(Received 1 December 1989; accepted 18 December 1989)

\section{Summary}

Interleukin-6(IL-6) is a pleiotropic cytokine previously known as B cell stimulatory factor (BSF-2), interferon- $\beta 2$ (IFN- $\beta 2$ ), $26-\mathrm{kDa}$ protein, and hepatocyte stimulating factor (HSF). The name IL-6 was proposed when the nucleotide sequences of the cDNAs for these proteins had been determined and the molecules were found to be identical. IL-6 production can be induced by a wide variety of agents in a wide range of cells, although IL-6 gene expression seems to be regulated in a tissue and stimulus specific manner. At least 3 different signal pathways regulate IL-6 gene expression, emphasizing its multiply inducible nature. The currently known activities of IL-6 include regulatory functions in hematopoiesis, immune reactions and acute phase responses. IL-6 appears to be a key member of the IL family; however, it is still poorly understood how IL-6 interacts with other lymphokines within the network. The anti-viral activity of IL-6 seems to be negligible. Elevated IL-6 levels have been found in diseases like rheumatoid arthritis, multiple myeloma and systemic lupus erythematosus. The abnormal expression and dysregulation of IL-6 in certain disorders may be a typical feature of this cytokine, making it the first cytokine that may be directly related to pathogenesis.

Key words: Interleukin-6; Historical background; Genetics; IL-6 induction; Biological activity; Dysregulation

Correspondence to: Dr. R. L. Marquet, Laboratory for Experimental Surgery, Erasmus University, P.O. Box 1738, 3000 DR Rotterdam, The Netherlands.

\section{Introduction}

The cells of the immune system communicate via soluble mediators called cytokines. These can be subdivided into lymphokines and monokines, predominantly produced by lymphocytes and monocytes-macrophages, respectively. The name interleukin was devised to designate 'between leukocytes'. As such, the name IL-1, for example, can now be seen as a real misnomer because it acts on a wider variety of tissues than was originally realized. In 1986 'interleukin' was given a more flexible definition, being redefined as a biological substance produced by cells of the immune system, albeit not exclusively, involved in inflammatory responses [1]. The primary amino acid sequence is the ultimate criterion used to assign an interleukin number to a substance. Interleukin-6 (IL-6) is a member of the interleukin family previously known as hybridoma growth factor (HGF), interferon $\beta$-2 (IFN- $\beta 2$ ), B-cell stimulatory factor (BSF-2) and hepatocyte stimulating factor (HSF). The name IL-6 was proposed when the nucleotide sequences of these proteins were determined and found to be identical $[2,3]$.

\section{Hybridoma growth factor: background}

In 1980 [4] it was reported that human endothelial culture supernatants contained a factor with strong growth-promoting activity for hybridoma cells in vitro. This factor was even capable of replacing feeder cells [5]. In 1986 an assay was developed by Lansdorp et al. [6] for what was then called 'hybridoma growth factor' (HGF). In this bioassay a murine antibody-producing B-cell hybridoma was used 
which depended for its growth on the presence of HGF [7]. Subsequently, a sensitive variant of this cell line was selected [8], permitting the measurement of HGF production by single cells. It was demonstrated that monocytes were the most active HGF producers. Weaker sources of HGF production turned out to be muscle cells, endothelial cells and cultured fibroblasts. It was found that HGF was a protein of $21 \mathrm{kDa}$ and $25 \mathrm{kDa}$ [7].

\section{Interferon $\beta-2$ : background}

Interferons (IFNs) are proteins which possess antiviral activity. Human IFNs are subclassified as $\alpha$, $\beta$ or $\gamma$, based on neutralization by specific antisera. Induced (especially induced by double-stranded poly(I)poly(C)RNA) human fibroblasts are known to be potent IFN producers. The major part of this IFN is a $20-\mathrm{kDa}$ glycoprotein called IFN- $\beta 1[9,10]$. In 1980 it was reported that human fibroblasts actually contain two IFN mRNAs. These two mRNAs have different sizes and translation products, and are not able to cross-hybridize [11]. Seghal et al. [12] succeeded in separating the two mRNAs. The 'new' mRNA (14S) appeared to code for a larger protein of $23-26 \mathrm{kDa}$. It was called $26-\mathrm{kD}$ a protein by some investigators $[13,14]$ and IFN- $\beta 2$ by others. After microinjection of either species of mRNA into oocytes, fully biologically active human IFN- $\beta$ was synthesized. It was found that the IFN- $\beta 2 / 26-\mathrm{kDa}$ gene, unlike the other IFN genes, was located on chromosome $7[15,16]$. Furthermore, the gene structure was very different. The IFN- $\alpha$, IFN- $\beta 1$ and IFN$\gamma$ are genes without introns, while IFN- $\beta 2$ contains at least three introns $[17,18]$. The overall homology between IFN- $\beta 1$ and IFN- $\beta 2$ is poor [19], indicating that the latter is a distinct species.

\section{B-cell stimulatory factor 2 (BSF-2/BCDF): back- ground}

In 1971 there was already speculation that soluble factors might be involved in the activation of B cells into Ig-secreting cells [20]. In rabbit $B$ cells it was shown [21] that this activation could be achieved via stimulation by anti-Ig and T cell-derived helper factors. Several other investigators [22-24] confirmed this observation in murine and human B cells. When somatic cell hybridization techniques made it possi- ble to immortalize and clone $\mathrm{T}$ cells, the factors involved in B cell maturation could be obtained [25]. One of these factors (BCDF) was purified [26] and was found to induce Ig secretion in Epstein-Barr virus transformed cell lines. It was able to induce $\mathrm{Ig}$ production in activated $B$ cells without any effect on cell growth [27]. At this time it was proposed that BCDF should be designated BSF-2. The same investigators who purified $\mathrm{BCDF}$, determined the partial amino acid sequence of $\mathrm{NH}_{2}$-terminal BCDF [28]. Hirano et al. [29] reported the molecular cloning, structural analysis and functional expression of the cDNA encoding BSF-2. They concluded that mature BSF-2 consisted of 184 amino acids and had a molecular mass of $20 \mathrm{kDa}$.

\section{Hepatocyte stimulating factor: background}

Acute inflammation is seen within a few hours after tissue damage or infection. The classic features of this reaction are heat, swelling, pain and loss of function. These signs are directly caused by alterations in the local vascular permeability. It is also caused by a series of metabolic reactions like fever, leukocytosis, increased muscle proteolysis, alterations in carbohydrate, lipid and trace mineral metabolism and changes in liver-derived plasma protein concentrations $[30,31]$. The acute reactions after trauma can be subdivided into non-hepatic and hepatic acute phase reactions. The hepatic part is almost completely regulated by HSF, originally described as fibrinogen stimulating factor [32]. Separation of the HSF activity, released by activated monocytes and macrophages, could be achieved by column and gel chromatographic procedures and was found to reside in the $25-30 \mathrm{kDa}$ protein fraction.

\section{Genetics of IL-6}

Three separate marker systems, $M s p I, B g l l$ and $B s t$ NI have been developed for the IL-6 gene [33]. MspI defines a three-allele system (8.0, 7.5 or $4.0 / 2.5 \mathrm{~kb}$ ) and $B g I \mathrm{I}$ a two-allele system (7.6 and $5.7 \mathrm{~kb}$ ). Both polymorphisms are likely to be due to base-pair substitutions. The polymorphism of $B s t \mathrm{NI}$ is due to DNA insertions of variable length. These insertions resulted in at least 4 different alleles, which can be detected by 10 different enzymes. 
The frequencies for all 3 systems have been analyzed and were found to differ in 6 human populations [34]. IL-6 has a highly polymorphic locus because all three sets of alleles occur in a variety of combinations. In situ hybridization experiments have assigned IL-6 to chromosome 7 p21-p15 [35]. Linkage studies between IL-6 and 27 other chromosome 7 markers place this gene between D7S135 and D7S370 at chromosome 7 p22-21 [33]. Combination of these results leads to the exact localization of the IL-6 gene: chromosome 7p21. Comparing the genomic sequence with the complementary DNA sequence it was found that the IL- 6 gene consists of 5 exons and 4 introns. The gene organization of IL- 6 is very similar to G-CSF, suggesting that these genes might have evolved from a common ancestor [36]. A characteristic feature of the mature IL-6 is its heterogeneity. All the known IL-6 producers have shown to produce multiple isoforms, caused by posttranslational and post-secretory modifications [37]. At this moment it is not sure whether these different modifications of IL-6 affect its properties.

\section{Regulation of IL-6 gene expression}

Many extracellular signals are able to activate a signal transduction pathway. Cyclic AMP and $\mathrm{Ca}^{2+}$ are the commonly used intracellular mediators of these pathways. Their concentrations can increase and decrease rapidly in response to extracellular signals because free $\mathrm{Ca}^{2+}$ and cyclic AMP is continuously removed. Rising cyclic AMP levels affect cells by stimulating cyclic AMP-dependent protein kinases. Increased free $\mathrm{Ca}^{2+}$ levels affect cells by altering the conformation of calmodulin, which in turn activates $\mathrm{Ca}^{2+}$-dependent protein kinases. Another important signal transduction pathway is the protein kinase c pathway. Shegal et al. [38] investigated which pathway is involved in the expression of the IL- 6 gene in human fibroblasts. It was found that protein kinase c-activating or $\mathrm{Ca}^{2+}$-elevating agents are able to increase the expression of the IL-6 gene and that the effect of the two together was at least additive. These observations were confirmed by Ray et al. [39] who further demonstrated that reagents that stimulate the cAMP-dependent pathways are able to activate the IL-6 gene. Zhang et al. [40] showed that the role for the cAMP-dependent pathway is independent of the protein kinase $\mathrm{c}$-controlled pathway.

Molecular studies [39, 41-43] revealed several potential transcriptional control elements in the region between -225 and -111 . It was shown that the three pathways discussed all converge in this region. The nucleotide sequence of this enhancer region is quite similar to the human c-fos gene. This gene can also be activated by the three pathways mentioned; the results of some experiments show that the two genes even share some of the transcription factors that regulate their expression. The fact that various signal transduction pathways are able to turn on the IL-6 expression underlines the multiply inducible nature of the gene. Investigation of which pathway is activated in response to a particular stimulus in a given cell has recently started. The preliminary data support the view that still unidentified signal transduction mechanisms also play a role.

\section{The variety of $\mathrm{IL}-6$ inducers and producers}

Many observations taken together validate the

TABLE 1

Physiological IL-6 stimuli.

\begin{tabular}{lll}
\hline & & References \\
\hline Cytokines & IL-1 & $44-46$ \\
& IL-2 & 50 \\
& TNF & 41,46 \\
& PDGF & 41,48 \\
& Interferons & 41,48 \\
& Lymphotoxin & 47,48 \\
Bacterial products & LPS & 47 \\
Growth factors & & \\
& EGF & 39 \\
& G-M-CSF & 51 \\
Trauma & CSF-1 & 51 \\
& Thermal injury & 52 \\
Viruses & Surgical injury & 53 \\
& & \\
Other & DNA-containing types & 48,56 \\
& RNA-containing types & 48,49 \\
& & 40 \\
\hline
\end{tabular}

TNF, tumor necrosis factor; PDGF, platelet-derived growth factor; LPS, lipopolysaccharide; EGF, epidermal growth factor; G$\mathrm{M}-\mathrm{CSF}$, granulocyte-macrophage colony stimulating factor. 
general idea that IL-6 gene expression can be induced by a wide variety of stimuli (Table 1). Research in order to reveal the molecular mechanisms involved showed that second messenger agonists are also able to induce IL-6 gene expression. These and other non-physiological stimuli are summarized in Table 2.

The cell types that can be activated to produce IL6 are distributed throughout the body (Table 3). The significance of this fact is probably that IL-6 has a role in local situations in the body besides its major systemic effect as HSF. Despite the wide variety of inducers and producers, there seems to be a tissuespecific and stimulus-specific regulation. For example, IL-1 is able to induce IL-6 production in fibroblasts and endometrial stromal cells, but not in peripheral blood monocytes. Monocytes, fibroblasts, keratinocytes and endothelial cells are activated by bacterial lipopolysaccharide to produce IL6 , in contrast to endometrial stromal cells. In addition, it is noteworthy that the different types of cells do not all produce the same amount of IL-6. Monocytes are potent producers of IL-6, while peripheral

TABLE 2

Non-physiological IL-6 stimuli.

\begin{tabular}{lll}
\hline & & References \\
\hline Protein kinase c activators & diC8 & 38,39 \\
& OAG & 40 \\
& TPA & 40 \\
& PMA & 38,39 \\
& & \\
$\mathrm{Ca}^{2+}$ elevating agents & A23187 & 38,39 \\
cAMP agonists & dbcAMP & 39,40 \\
& Forskolin & 39,46 \\
& 3-Isobutyl & \\
& methylxanthine & 39,40 \\
& Cholera toxin & 40 \\
& & \\
Other & Poly(I)poly(C) & 45 \\
& Cycloheximine & 45,54 \\
& Actinomycin D & 45,54 \\
& Serum (bovine) & $38-40$ \\
& Anti-C3 antibody & 55 \\
\hline
\end{tabular}

diC8, 1,2-dioctanoylglycerol; OAG, 1-oleoyl-2-acetylglycerol; TPA, 12-O-tetradecanoylphorbol-13-acetate; PMA, phorbol12-myristate-acetate; A23187, calcium ionophore; dbcAMP, dibutyryl cAMP.
TABLE 3

Cell types that can produce IL-6.

\begin{tabular}{ll}
\hline & References \\
\hline Fibroblasts & 45,54 \\
Epithelial cells, keratinocytes & 39,57 \\
Endothelial cells & $39,44,47$ \\
Endometrial stromal cells & 58 \\
Monocytes/macrophages; microglial cell lines & $39,41,51$, \\
& 60 \\
Kuppfer cells & 59 \\
B cells & 60 \\
T cells & 60 \\
Tumor cells (hematopoietic and non- & 40,60 \\
hematopoietic) & 61 \\
Hepatocytes & 62 \\
Pancreatic $\beta$ cells & \\
\hline
\end{tabular}

blood $\mathrm{T}$ lymphocytes make less than $1 \%$ of the amount produced by monocytes. Attempts to elucidate the biochemical basis for these tissue-specific differences have hitherto been unsuccessful.

\section{The IL-6 receptor}

Until 1987 no information was available about the IL-6 receptor. This situation was changed by the studies of Taga et al. [63]. It was reported that human lymphoblastoid CESS cells [63, 64] expressed high-affinity binding sites for IL-6. Because binding of radioactive IL-6 was not competitively inhibited by IL-1, IL-2, IFN- $\beta$, IFN- $\gamma$ or G-CSF, it seemed to be a specific receptor. The isolation and characterization of the IL-6 receptor was difficult because of the small number of IL-6 receptors on the average cell (100-1000 per cell). Utilizing a high-efficiency IL-6 receptor expression system, Yamasaki et al. [65] isolated the complementary DNA of the IL-6 receptor. The nucleotide sequence was confirmed by combining several sets of sequence data. The IL-6 receptor consists of 468 amino acids and has two hydrophobic regions (region 1-20 and region $359-386$ ). The first region is considered to be a signal peptide, and the latter is presumably a transmembrane domain. Comparing the IL-6 receptor with data from the National Biomedical Research Foundation database and Genetic Sequence Data Bank homologies were found with members of the immunoglobulin superfamily. A domain of 90 ami- 
no acids (between positions 20 and 110 ) is similar to a domain in the immunoglobulin superfamily. Unlike some other growth factors, the IL-6 receptor has no tyrosine kinase domain, indicating a different signal transduction pathway.

\section{Biological activities}

IL-6 is able to act in a number of ways, such as having direct effects, mediating the effects of other cytokines, interacting with glucocorticoids and having co-agonistic or antagonistic effects with other cytokines (Table 4).

It is a true pleiotropic cytokine with action in many cellular systems. The molecule appears to be involved in coordinating functions during hematopoiesis, immune regulation and the acute phase response. For example, IL-6 controls the growth or proliferation of early progenitor cells in primary lymphoid organs and sustains antibody production. Moreover, the production of IL-6 in response to inducers like viruses and bacteria indicates a central role in host defense mechanisms.

In a recent article by Revel et al. [84] it was suggested that IL-6 may also have several antitumor activities, including inhibition of cancer cell growth, differentiation of malignant cells to more normal phenotypes and the stimulation of complement synthesis. Since it was reported [85] that IL-6, tumor necrosis factor (TNF) and IL-1 genes are transcribed

\section{TABLE 4}

Biological effects of IL-6.

\begin{tabular}{|c|c|c|}
\hline Effect & & Ref. \\
\hline \multicolumn{3}{|l|}{ Direct effects } \\
\hline \multirow[t]{4}{*}{ Hematopoiesis } & Granulocyte-macrophage colony formation & 66 \\
\hline & Stimulation of erythropoiesis & 68 \\
\hline & Differentiation of leukemia cells into macrophage-like cells & 69 \\
\hline & Triggering of quiescent stem cells & 66 \\
\hline \multirow[t]{6}{*}{ Immune system } & B-cell differentiation into antibody-producing cells & 29 \\
\hline & Growth factor for EBV-transformed B cells & 27 \\
\hline & Proliferation of hybridoma cell lines & 43 \\
\hline & IL-2 expression of activated thymocytes & 73 \\
\hline & MHC antigen expression & 59 \\
\hline & Activation of NK cells & 75 \\
\hline Neural system & Nerve growth factor-like activity & 76 \\
\hline \multirow[t]{5}{*}{ Acute phase responses } & Induction of acute phase proteins & 39,77 \\
\hline & Inhibition of PEPCK activity & 80 \\
\hline & Induction of fever & 81 \\
\hline & ACTH release & 82 \\
\hline & Increased uptake of non-metabolizable amino acids by hepatocytes & 83 \\
\hline \multicolumn{3}{|c|}{ Coagonistic effects (with other cytokines and glucocorticoids) } \\
\hline \multirow[t]{4}{*}{ IL-6 and IL-6 } & Second signal for IL-2 expression on CD4 cells & 70 \\
\hline & T-cell activation & 71 \\
\hline & Growth of thymocytes (with IL-2) & 72,73 \\
\hline & Induction of certain acute phase proteins & $39,78,79$ \\
\hline IL-6 and IL-2 & Development of cytotoxic cells from immature $T$ cells (with IFNs) & 66,74 \\
\hline IL-6 and IL-3 & Proliferation of pluripotent hemopoietic progenitors & 67 \\
\hline IL-6 and glucocorticoids & Induction of certain acute phase proteins & 39 \\
\hline
\end{tabular}


at high levels in the organs of normal individuals, it became clear that these cytokines were able to function as endogenous regulators. At present it is still not understood how IL-6 interacts with other members of the cytokine network although it appears to be a key member of this network.

\section{Does IL-6 exhibit antiviral activity?}

It was reported by Revel et al. [17, 19] that IFN- $\beta 2$ genes, when transfected into Chinese Hamster Ovary $(\mathrm{CHO})$ cell clones, produce antivirally active human IFN after induction. The highest specific activity obtained, is less than $1 \%$ of what is found for IFN- $\beta 1$ or for most IFN- $\alpha$ S and can be neutralized using IFN- $\beta$ antiserum. On the other hand it was shown [27] that natural purified BSF-2 did not show sny IFN activity. A later article [86] reported that Escherichia coli-derived recombinant BSF-2 did not display any detectable antiviral activity, and that it was not possible to neutralize the immunoglobulininducing activity of BSF- 2 with anti-IFN $\beta$. Immunoblots of the IFN- $\beta 2$ (CHO-derived) revealed two IL- 6 bands, 66 and $23 \mathrm{kDa}$, the $26-\mathrm{kDa}$ form being absent [84]. In a general discussion [87] it was concluded by several groups (Sehgal, Revel) that the $23-30 \mathrm{kDa}$ IL-6 forms have no antiviral activity in contrast to the $66-\mathrm{kDa}$ protein. However, this antiviral activity should not be considered physiologically important.

\section{Dysregulation of IL-6 production}

Clinical studies have shown that IL-6 is a cytokine participating in many pathological processes. Dysregulation of IL-6 production seems to play a crucial role in several diseases, such as autoimmune diseases, lymphoid malignancies and carcinomas.

\subsection{Rheumatoid arthritis}

Rheumatoid arthritis is a chronic autoimmune disorder that is mainly expressed in the joints, but which also has multiple systemic manifestations. In the synovial fluid from patients with rheumatoid arthritis, IL-1 [88] and TNF [89] have been demonstrated. These cytokines may be involved in the pathogenesis of joint destruction because their biological activities have been demonstrated to relate with the destruction of bone [90]. IL-6 is spontaneously produced by synoviocytes in vitro and its synthesis can be up-regulated by TNF and IL-1 [91]. Various reports [92-94] have shown that the levels of IL-6 were considerably elevated (more than 1000fold) in the synovial fluid of rheumatoid patients, whereas there was little IL-6 activity in the serum. This indicates that IL-6 is produced locally in the inflamed joint and diffuses into the circulation. A most remarkable finding was that there appeared to be an association between IL-6 levels and disease activity [93, 94]. Increased IL-6 production has been found not only in rheumatoid synovium, but also in other types of inflammatory synovitis [93].

\subsection{Multiple myeloma}

Multiple myeloma is a disease in which there is a malignant transformation in a single antibodyproducing cell which leads to a high immunoglobulin concentration in the serum. Knowing that IL-6 is a potent growth factor for myeloma cells [5], it was suggested that expression of IL-6 or its receptor could be responsible for the oncogenesis of multiple myeloma. Indeed, it was found that an autocrine IL6 loop was required for the generation of human myelomas [95]. Recently, it has been demonstrated [60] that the IL-6 responsiveness of myeloma cells in vitro is directly correlated with in vivo myeloma cell proliferation and disease severity.

\subsection{Acute infectious neural diseases}

Analysis of IL-6 activity in a wide scala of neural diseases revealed elevated IL-6 levels in the cerebrospinal fluid (CSF) of patients with acute infections (viral meningitis, bacterial meningitis, tuberculous meningitis, herpes simplex encephalitis). These elevated IL-6 levels were not found in chronic or non-infectious neural diseases.

\subsection{Trauma}

Severely burned patients display a systemic inflammatory reaction, called the acute phase response. In such patients it was found that within hours after injury, IL-6 had risen to up to 100 times the normal level [52], suggesting a causal role for IL6 in this reaction. Also, surgical trauma has been 
found to be associated with high levels of IL-6 activity, reaching peak levels two days after the operation $[53,96]$.

\section{5. $A I D S$}

One of the immunological abnormalities seen in AIDS patients is polyclonal B-cell activation leading to hypergammaglobulinemia. Because IL-6 plays an essential role in the differentiation of activated $B$ cells into antibody-producing cells, the effect of HIV on the IL-6 induction was studied [49]. Indeed, it was found that HIV induces overproduction of IL-6.

\subsection{Systemic lupus erythematosus (SLE)}

Systemic lupus erythematosus (SLE) is a chronic inflammatory disease, involving almost any organ system. One of its major immunological features is B cell hyperactivity. SLE B cells showed spontaneous activation by in vitro culture without any stimulation. In order to reveal the underlying mechanism(s) of this phenomenon, several groups studied the lymphokine production by B cells in patients with SLE. Tanaka et al. [97] described that lymphokines, including IL- $1 \alpha$, IL-4 and IL-6, were spontaneously produced by SLE B cells. These interleukins interact as an autocrine mechanism to induce the hyperactivity of SLE B cells.

\subsection{Cardiac myxoma}

Cardiac myxoma can be considered as an autoimmune-like syndrome. It is a benign intraatrial heart tumor frequently associated with autoimmune-like symptoms, including autoantibody production [28]. These clinical abnormalities usually disappear after surgical removal of the tumor. In vitro studies with cardiac myxoma cells demonstrated that these cells spontaneously produce IL-6, suggesting that this interleukin may be responsible for the clinical symptoms. However, a recent article [98] reported that IL-6 serum levels also were elevated in animals bearing a variety of tumors (sarcomas, melanomas and adenocarcinomas). IL6 , detected as a consequence of the tumor-bearing state, may therefore be an indicator of the host responses to malignancy [84].

\subsection{Transplantation}

Apart from being involved in the pathogenesis of certain diseases, IL-6 seems to be involved in the acute rejection of a transplant. Van Oers et al. [53] demonstrated elevated serum and urine levels directly after renal transplantation (surgical trauma) and during acute rejection episodes. It was suggested that IL-6 measurements might be useful in monitoring of early rejection in renal transplant patients.

\section{Concluding remarks}

IL-6 seems to be one of the most pleiotropic cytokines yet discovered. It has the capacity to cause clinical abnormalities, directly or indirectly, by nonphysiological overproduction during the course of several diseases. Although only the contribution of IL-6 is discussed in this minireview, it is clear that the full clinical manifestations of these diseases are likely to be the result of several cytokines acting in concert. Furthermore, a defect in IL-6 production, either alone or in combination with other cytokines, appears to lead to the development of various diseases, usually via a dysregulated autocrine mechanism. If the exact role of IL- 6 in the pathogenesis of the above-mentioned diseases can be unraveled, a role for anti-IL-6 therapy (anti-IL-6 antibodies, antiIL-6 receptor antibodies, IL-6 antagonists or IL-6 linked to a toxin) for these diseases can be envisaged. In addition, in the near future it may become apparent whether some of these diseases are related to the genetic polymorphism of IL-6.

\section{References}

[1] Smith, K. A. (1986) Immunol. Today 7, 321.

[2] Van Damme, J., Cayphas, S., Van Snick, J., Conings, R., Lenaerts, J. P., Simpson, R. J. and Billiau, A. (1987) Eur. J. Biochem. 168, 543.

[3] Poupart, P., Vandenabeele, P., Cayphas, S., Van Snick, J., Haegeman, G., Kruys, V., Fiers, W. and Content, J. (1987) EMBO J. 6, 1219.

[4] Astaldi, G. C. B., Janssen, M. C., Lansdorp, P. M., Willems, C., Zeylemaker, W. P. and Oosterhof, F. (1980) J. Immunol. 125, 1411.

[5] Astaldi, G. C. B., Janssen, M. C., Lansdorp, P. M., Zeylemaker, W. P. and Willems, C. (1981) J. Immunol. 126, 1170.

[6] Lansdorp, P. M., Aarden, L. A., Calafat, J. and Zeylemaker, W. P. (1987) Mechanisms in B-cell neoplasia. 132, 105.

[7] Aarden, L. A., Lansdorp, P. M. and De Groot, E. R. (1985) Lymphokines 10, 175 . 
[8] Aarden, L. A., De Groot, E. R., Schaap, L. O. and Lansdorp, P. M. (1987) Eur. J. Immunol. 17, 1411.

[9] Knight, E. J., Hunkapillar, M. W., Korant, B. D., Hardy, R. W. F. and Hood, L. E. (1980) Science 207, 525.

[10] Taniguchi, T., Ohno, S., Fuju-Kuriyama, Y. and Muramatsu, M. (1980) Gene 10, 11.

[11] Weissenbach, J., Chernajovsky, J., Zeevi, M., Shulman, L., Soreq, H., Nir, H., Wallach, D., Perricaudet, M., Tiollais, P. and Revel, M. (1980) Proc. Natl. Acad. Sci. USA 77, 7152.

[12] Seghal, P. B. and Sagar, A. D. (1980) Nature 288, 95.

[13] Content, J., De Wit, L., Poupart, P., Opdenakker, G., Van Damme, J. and Billiau, A. (1985) Eur. J. Biochem. 152, 253.

[14] Haegeman, G., Content, J., Volckaert, G., Derynck, R., Tavernier, J. and Fiers, W. (1986) Eur. J. Biochem. 159, 625.

[15] Revel, M., Ruggieri, R. and Zilberstein, A. (1986) in: The Biology of the Interferon System, 1985 (W. E. Stewart and H. Schellekens, Eds.) Elsevier, Amsterdam.

[16] Seghal, P. B., Zilberstein, A., Ruggieri, M. R., May, L. T., Ferguson-Smith, A., Slate, D. L., Revel, M. and Ruddle, F. H. (1986) Proc. Natl. Acad. Sci. USA 83, 5219.

[17] Revel, M. (1983) Interferon 5, 205.

[18] Zilberstein, A., Ruggieri, R. and Revel, M. (1985) The interferon system, Sereno Symposia, 73. Academic Press, New York.

[19] Zilberstein, A., Ruggieri, R., Korn, J. H. and Revel, M. (1986) EMBO J. 5, 2529.

[20] Dutton, R. W., Falkoff, R., Hirst, J. A., Hoffman, M., Kappler, J. W., Kettman, J. R., Lesley, J. R. and Vann, P. (1971) Progr. Immunol. 1, 355.

[21] Kishimoto, T., Miyaka, T., Nishizawa, Y., Watanabe, T. and Yamamura, Y. (1975) J. Immunol. 115, 1179.

[22] Parker, D. C., Fothergill, J. J. and Wadsworth, D. C. (1979) J. Immunol. 123, 931.

[23] Isakson, P. C., Pure, E., Uhr, J. W. and Vitetta, E. S. (1981) Proc. Natl. Acad. Sci. USA 78, 2507.

[24] Yoshizaki, K., Nakagawa, T., Kaieda, T., Muraguchi, A., Yamamura, Y. and Kishimoto, T. (1982) J. Immunol. 126, 1296.

[25] Leanderson, T., Lundgren, E., Ruuth, E., Borg, H., Persson, H. and Coutinho, A. (1982) Immunology 79, 7455.

[26] Kishimoto, T., Yoshizaki, K., Kimoto, M., Okada, M., Kuratani, T., Kikutani, H., Shimizu, K., Nakagawa, T., Nakagawa, N., Miki, Y., Kishi, H., Fukunaga, K., Yoshikubo, T. and Taga, T. (1984) Immunol. Rev. 78, 97

[27] Hirano, T., Taga, T., Nakano, N., Yasukawa, K., Kashiwamura, S., Shimizu, K., Nakajima, K., Pyun, K. H. and Kishimoto, T. (1985) Proc. Natl. Acad. Sci. USA 82, 5490 .

[28] Hirano, T., Taga, T., Yasukawa, K., Nakajima, K., Nakano, N., Takatsuki, F., Shimizu, M., Murashima, A., Tsunasawa, S., Sakiyama, F. and Kishimoto, T. (1987) Proc. Natl. Acad. Sci. USA 84, 228.

[29] Hirano, T., Yasukawa, K., Harada, H., Taga, T., Watanabe, Y., Matsuda, T., Kashiwamura, S-i., Nakajima, K., Koyama, K., Iwamatsu, A., Tsunasawa, S., Sakiyama, F., Matsui, H., Takahara, Y., Taniguchi, T. and Kishimoto, T. (1986) Nature 324, 73.

[30] Tillett, W. S. and Francis, T. (1930) J. Exp. Med. 52, 561.

[31] Abernethy, T. J. and Avery, O. T. (1941) J. Exp. Med. 73, 173.

[32] Richie, D. G. and Fuller, G. M. (1981) Inflammation 5, 275.
[33] Bowcock, A. M., Kidd, J. R., Lathrop, G. M., Daneshvar, L., May, L. T., Ray, A., Sehgal, P. B., Kidd, K. K. and Cavalli-Sforza, L. L. (1988) Genomics 3, 8.

[34] Bowcock, A. M., Ray, A., Erlich, H. A. and Sehgal, P. B. (1989) Ann. NY Acad. Sci. 557, 345.

[35] Ferguson-Smith, A. C., Cher, Y.-F., Newman, M. S., May, L. T., Sehgal, P. B. and Rudde, F. H. (1988) Genomic 2, 203.

[36] Yasukawa, K., Hirano, T., Watanabe, Y., Muratani, K., Matsuda, T., Nakai, S. and Kishimoto, T. (1987) EMBO J. 6, 2939.

[37] May, L. T., Santhanam, U., Tatter, S. B., Ghrayer, J. and Sehgal, P. B. (1989) Ann. NY Acad. Sci. 557, 114.

[38] Sehgal, P. B., Walther, Z. and Tamm, I. (1987) Proc. Natl. Acad. Sci. USA 84, 3663.

[39] Ray, A., Tatter, S. B., May, L. T. and Sehgal, P. B. (1988) Proc. Natl. Acad. Sci. USA 85, 6701.

[40] Zhang, Y., Lin, Y.-X. and Vilcek, J. (1988) J. Biol. Chem. $263,6177$.

[41] Walther, Z., May, L. T. and Sehgal, P. B. (1988) J. Immunol. 140, 974.

[42] Ray, A., Tatter, S. B., Santhanam, U., Helfgott, D. C., May, L. T. and Sehgal, P. B. (1989) Ann. NY Acad. Sci. 557, 353.

[43] Matsuda, T., Sumatsu, S., Kawano, M., Yoshizaki, K., Tang, B., Tanabe, O., Nakajima, T., Akira, S., Hirano, T. and Kishimoto, T. (1989) Ann. NY Acad. Sci. 557, 466.

[44] Sironi, M., Breviario, F., Proserpio, P., Biondi, A., Vecchi, A., Van Damme, J., Dejana, E. and Mantovani, A. (1989) J. Immunol. 142, 549 .

[45] Van Damme, J., Cayphas, S., Opdenakker, G., Billiau, A. and Van Snick, J. (1987) Eur. J. Immunol. 17, 1.

[46] Zhang, Y., Lin, J. X., Yip, Y. K. and Vilcek, J. (1989) Ann. NY Acad. Sci. 557, 548

[47] Jirik, F. R., Podor, T. J., Hirano, T., Kishimoto, T., Loskutoff, D. J., Carson, D. A. and Lotz, M. (1989) J. Immunol. 142, 144.

[48] Sehgal, P. B., Helfgott, D. C., Santhanam, U., Tatter, S. B., Clarink, R. H., Ghrayeb, J. and May, L. T. (1988) J. Exp. Med. 167, 1951

[49] Nakajima, K., Martinez-Maza, O., Hirano, T., Breen, E. C., Nishanian, P. G., Salazzar-Gonzalez, J. F., Fahly, J. L. and Kishimoto, T. (1989) J. Immunol. 142, 531.

[50] Kasid, A., Director, E. P. and Rosenberg, S. A. (1989) Ann. NY Acad. Sci. 557, 564.

[51] Navarro, S., Debili, N., Bernaudin, J. F., Vainchenker, W. and Doly, J. (1989) J. Immunol. 142, 4339.

[52] Nysten, M. W. N., De Groot, E. R., Ten Duis, H. J., Klasen, H. J., Hack, C. E. and Aarden, L. A. (1987) Lancet ii, 921.

[53] Van Oers, M. H. J., Van der Heyden, A. A. P. A. M. and Aarden, L. A. (1988) Clin. Exp. Immunol. 71, 314-319.

[54] Content, J., De Wit, L., Pierard, D., Derynck, R., De Clercq, E. and Fiers, W. (1982) Proc. Natl. Acad. Sci. USA 79, 2768

[55] Krutmann, J., Kirnbauer, R., Kock, A., Schwarz, T., May, L. T., Sehgal, P. B. and Luger, T. A. (1989) submitted for publication.

[56] Wong, G. H. W. and Goeddel, D. V. (1986) Nature 323, 819.

[57] Kuppers, T. S., Min, K., Sehgal, P. B., Mizutani, H., Birch all, N., Ray, A. and May, L. (1989) Ann. NY Acad. Sci. 557, 454.

[58] Tabibzadeh, S. S., Santhanam, U., Sehgal, P. B. and May, L. T. (1989) J. Immunol. 142, 3134. 
[59] May, L. T., Ghrayeb, J., Santhanam, U., Tatter, S. B., Sthoeger, Z., Helfgott, D. C., Chiorazzi, N., Grieninger, G. and Sehgal, P. B. (1988) J. Biol. Chem. 263, 7760-7766.

[60] Zhang, X. G., Klein, B. and Bataille, R. (1989) Blood, 74, 11.

[61] Lotz, M., Zuraw, B. L., Carson, D. A. and Jirik, R. (1989) Ann. NY Acad. Sci. 557, 509.

[62] Campbell, I. L., Cutri, A., Wilson, A. and Harrison, L. C. (1989) J. Immunol. 143, 1188.

[63] Taga, T., Kawanashi, Y., Hardy, R. R., Hirano, T. and Kishimoto, T. (1987) J. Exp. Med. 166, 967.

[64] Couli, P. G., Vanhecke, A., Van Damme, J., Cayphas, S., Poupart, P., De Wit, L. and Content, J. (1987) Eur. J. Immunol. 17, 1435.

[65] Yamasaki, K., Taga, Y., Hirata, Y., Yawata, H., Kawanishi, Y., Seed, B., Taniguchi, T., Hirano, T. and Kishimoto, T. (1988) Science 241, 825

[66] Clark, S. C. (1989) Ann. NY Acad. Sci. 557, 438.

[67] Ikebuchi, K., Wong, G. G., Clark, S. C., Ihle, J. N., Hirai, Y. and Ogawa, M. (1987) Proc. Natl. Acad. Sci. USA 84 9035.

[68] Ulich, T. R., Del Castillo, J. and Guo, K. (1989) Blood. 73, 108.

[69] Miyaura, C., Onozaki, K., Akiyama, Y., Taniyama, T., Hirano, T., Kishimoto, T. and Suda, T. (1988) FEBS Lett. 234,17

[70] Garman, R. D., Jacobs, K. A., Clark, S. C. and Raulet, D. H. (1987) Proc. Natl. Acad. Sci. USA 84, 7629.

[71] Mizutani, H., May, L. T., Sehgal, P. B. and Kupper, T. S. (1989) J. Immunol. 143, 896.

[72] Elias, J. A., Trinchieri, G., Beck, J. M., Simon, P. L., Seh gal, P. B., May, L. T. and Kern, J. A. (1989) J. Immunol. 142, 509.

[73] Le, J., Fredrickson, G., Pollack, M. and Vilcek, J. (1989) Ann. NY Acad. Sci. 557, 444.

[74] Takai, Y., Wong, G. G., Clark, S. C., Burakoff, S. J. and Hermann, S. H. (1989) J. Immunol. 140, 508.

[75] Luger, T. A., Schwarz, T., Krutmann, J., Kirnbauer, R., Neuner, P., Kock, A., Urbanski, A., Borth, W. and Schauer, E. (1989) Ann. NY Acad. Sci. 557, 405.

[76] Satoh, T., Nakamura, S., Taga, T., Matsuda, T., Hirano, T., Kishimoto, T. and Kaziro, Y. (1988) Mol. Cell. Biol. 8, 3546.

[77] Castell, J. V., Andus, T., Kunz, D. and Heinrich, P. C. (1989) Ann. NY Acad. Sci. 557, 87.

[78] Moldawer, L. L., Bushman, E. D., Barber, A., Marano, M. A., Keogh, C., Fong, Y., Helfgott, D. C., May, L. T., Seh- gal, P. B. and Lowry, S. F. (1989) Ann. NY Acad. Sci. 557, 528.

[79] Perlmutter, D. H. (1989) Ann. NY Acad. Sci. 577, 332.

[80] Hill, M. R., Stith, R. D. and McCallum, R. E. (1989) Ann. NY Acad. Sci. 557, 502.

[81] Dinarello, C. A., Cannon, J. G., Endres, S., Lonnemann, G., Miller, L. C., Ikejima, T., Schindler, R., Ghezzi, P. and Van der Meer, J. W. M. (1988) Eur. J. Clin. Invest. 18, A50.

[82] Klasing, K. C. (1988) J. Nutr. 118, 1436.

[83] Koj, A. (1989) Ann. NY Acad. Sci. 557, 1.

[84] Revel, M., Zilberstein, A., Chen, L., Gotthelf, Y., Barash, I. Novick, D., Rubinstein, M. and Michalevicz, R. (1980) Ann. NY Acad. Sci. 557, 144.

[85] Tovey, M. G., Content, J., Gresser, I., Gugenheim, J., Blanchard, B., Guymarho, J., Poupart, P., Gigou, M., Shaw, A. and Fiers, W. (1989) J. Immunol. 141, 3106.

[86] Hirano, T., Matsuda, T., Hosoi, K., Okano, A., Matsui, H. and Kishimoto, T. (1988) Immunol. Lett. 17, 41.

[87] General discussion: antiviral effects. (1989) Ann. NY Acad. Sci. 557, 162.

[88] Wood, D. D., Ihrie, E. J., Dinarello, C. A. and Cohen, P. L. (1983) Arthr. Rheum. 26, 975.

[89] Duff, G., Giovine, F. D., Dickens, E., Symons, J., Wood, N., Carter, D. and Manson, J. (1987) Immunobiology 175, 10.

[90] Le, J. and Vilcek, J. (1987) Lab. Invest. 56, 234.

[91] Guerne, P. A., Zuraw, B. L., Vaughan, J. H., Carson, D. A. and Lotz, M. (1989) J. Clin. Invest. 83, 585.

[92] Houssiau, F. A., Devogelaer, J. P., Van Damme, J., Nagant De Deuxchaisnes, C. and Van Snick, J. (1988) Arthr. Rheum. 31,784 .

[93] Waage, A., Kaufmann, C., Espevik, T. and Husby, G. (1989) Clin. Immunol. Immunopathol. 50, 394.

[94] Swaak, A. J., Van Rooyen, A., Niewenhuis, E. and Aarden, L. A. (1988) Scand. J. Rheum. 17, 469.

[95] Kawano, M., Hirano, T., Matsuda, T., Taga, T., Horii, Y., Iwato, K., Asaoku, H., Tang, B., Tanabe, O., Tanake, H., Kuramoto, A. and Kishimoto, T. (1988) Nature 332, 83.

[96] Nishimoto, N., Yoshizaki, K., Tagoh, H., Monden, M., Kishimoto, S., Hirano, T. and Kishimoto, T. (1989) Clin. Immunol. Immunopathol. 50, 399.

[97] Tanaka, Y., Saito, K., Shirakawa, F., Ota, T., Suzuki, H., Eto, S. and Yumashita, U. (1988) J. Immunol. 141, 3043.

[98] McIntosh, I. K., Jablons, D. M., Mule, J. J., Nordan, R. P., Rudikoff, S., Lotze, M. T. and Rosenberg, S. A. (1989) J. Immunol. 143, 162. 